\title{
Mary Queen of Scots: the 'daughter of debate'
}

\author{
Lesley Smith
}

\section{Mary Stuart - the woman}

Mary Stuart, known as Mary Queen of Scots, was a remarkable specimen of humanity. She was 5'11" in height when the average woman was around 4'11", so she was the equivalent of a woman 6'5" by modern standards and probably one of the tallest women in Europe. With thick glossy red hair almost to her waist, she spoke five languages, was well educated and queen of two nations, Scotland (at 6 days old) and France (at 16 years of age). According to the Catholic Church, which held sway over the vast majority of Europe, Mary was the legitimate heir to the English throne, as Henry VII was her great grandfather, Henry VIII her great uncle and Elizabeth I her second cousin. Henry's marriage to Anne Boleyn was not recognised by the Catholic Church as a divorce had not been granted and Elizabeth had been declared a bastard by her own father. Elizabeth had Parliament reverse her bastardisation, as they had previously done for her halfsister Mary Tudor, who reigned before her as Mary I.

Mary Stuart presented a fit and healthy body. She was the first woman to play golf at St Andrews, had her own billiard table, and on one occasion rode 40 miles sidesaddle in a single day to be with James Hepburn, who later became her third husband. Mary Stuart was also beautiful and very sexually attractive. Unlike Elizabeth, Mary was prepared to marry and had borne a son. She was also 9 years younger than Elizabeth. All in all, Mary Queen of Scots was a very dangerous creature to the unmarried Protestant Elizabeth, and her physical presence made her positively intoxicating to anyone who met her.

\section{Mary Stuart's imprisonment}

In April 1569, Mary rode into Tutbury Castle in Staffordshire (which is currently in my keep) surrounded by armed guards. She was, in fact, arriving at her first official English prison, and would be held at Tutbury four times. In total her captivity lasted for nearly 19 long years until her execution by decapitation on 8 February 1587 at Fotheringhay in Northamptonshire.

Elizabeth had always been wary of Mary, not only for all her royal rights and physical glamour but also because at her French Coronation celebrations, Joachim du Bellay said publicly for all to hear, including the English Ambassador: "Through you, France and England will change the ancient war into a lengthy peace that will be handed down from father to son". This statement suggested that by her marriage, Mary would make Scotland and England provinces of France. One can only imagine how angry Elizabeth was on receiving the report of this statement.

Elizabeth has been much criticised for holding Mary prisoner for so long without proper trial or evidence that she should be held. It was said at the time that Mary might well have been involved in the death of her second husband, Darnley, who was also the father of her son, James. Henry Darnley was murdered at Kirk O'Fields in

J Fam Plann Reprod Health Care 2008; 34(2): 125-127

Tutbury Castle, Tutbury, UK

Lesley Smith, Curator

Correspondence to: Lesley Smith, Tutbury Castle, Tutbury, Staffordshire DE13 9JF, UK. E-mail: info@tutburycastle.com

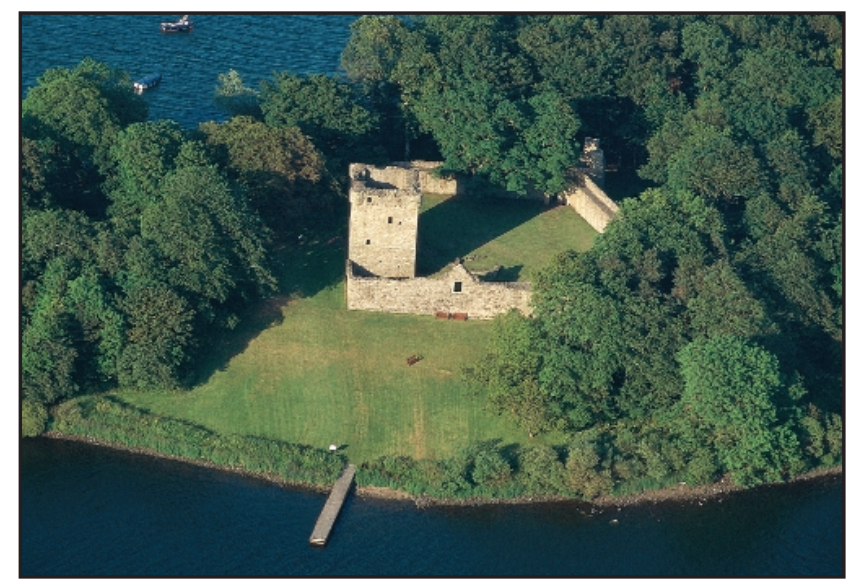

Figure 1 Loch Leven Castle in Kinross, Scotland, where Mary Stuart was imprisoned and where she is reported to have miscarried twins in 1567. (C) Crown copyright reproduced courtesy of Historic Scotland

Edinburgh on 10 February 1567. Mary was implicated because Darnley's death left her free to marry the man for whom she had a clear passion, James Hepburn, 4th Earl of Bothwell, whom she married on 15 May 1567. Bothwell was the main suspect for the murder.

Why is this tragic and passionate Queen being offered as an article of interest in a medical publication such as this one? Quite simply because Mary's guilt as an adulteress and liar and the perception of her sexual behaviour revolves, in my opinion, around a miscarriage that happened in Loch Leven Castle on 24 July 1567 (Figure 1). That miscarriage might also, in part, explain why Elizabeth I took steps to control Mary through imprisonment on account of what she knew of Mary's behaviour. We don't truly know what Elizabeth knew about Mary's life and actions but we do know that Elizabeth not only had a brilliant mind but also surrounded herself with some of the greatest advisors in English history, and maintained a network of spies, including in Scotland. I set out to bring together historical and medical research to try and solve one of the great mysteries of the past.

\section{Unfolding of events}

Mary married the Earl of Bothwell so soon after the murder of her husband because it was claimed she had been raped by Bothwell on or about 24 April 1567, having been carried off by him to his castle in Dunbar. For the following 10 days or so Bothwell went to Edinburgh to see to the small matter of his divorce so he could be free to marry Mary, claiming her as his own following the rape. During her time at Dunbar, Mary was left by Bothwell for days at a time without any recorded attempt to escape, this in spite of Mary's physical strength and ability to ride long distances making escape a realistic option. Admittedly, Mary may have been unwell at the time and unable to ride, but even her most ardent apologists admit that her remaining at Dunbar makes the rape story questionable.

There is another argument. Mary despised her husband Darnley, following his involvement in the murder of her musician and secretary, David Rizzio, in her presence at Holyrood Palace in 1566 when she was 7 months' pregnant. Darnley was weak, petulant, bisexual, vainglorious and inclined to rages. He was treated in 
Glasgow with a remedy known as salivation of mercury for syphilis. This syphilis could also be crucial to the unfolding story.

Mary was separated from Darnley and had been for some time, and yet by coincidence she spent a night in Kirk O'Fields the night before Darnley was murdered on 10 February 1567 . Her rooms had a connecting staircase to his.

Let us now look at the events that followed, including Mary effectively being removed from the throne of Scotland for this scandal and being imprisoned in Loch Leven Castle where she suffered the miscarriage.

\section{January $1567 \quad$ Darnley treated for syphilis in Glasgow}

10 February 1567 Death of Darnley at Kirk O’Fields 24 April $1567 \quad$ Mary visited her son for the last time at Stirling and was abducted on her way back to Edinburgh

15 May 1567

24 July 1567 Mary married Bothwell at Holyrood Mary miscarried twins

The documented source of the miscarriage of the twins was Mary's close adviser and secretary, Claude Nau. Nau was not part of Mary's party at Loch Leven, joining her entourage only during the final decade of her life in English custody. However, nobody seems inclined to dismiss Nau's memoirs, as he was a highly educated man and his contemporary observations are a well-respected source. Nau's papers were published posthumously as The History of Mary Stewart in Edinburgh in 1883 by Paterson. They state: "When prevailed upon to sign her abdication, she was lying on her bed in a state of very great weakness, partly in consequence of a great flux, the result of a miscarriage of twins, her issue of Bothwell. Soon after, she had a swelling of one half of her body and one leg, perhaps as phlegmasia alba dolens".

Nau records the event as happening on the 24th day of July 1567 as an "avortment de deux enfants". We don't know if Mary was aided in her labour, but it is known that women could have a dead fetus removed by a hook in the eye socket. No mention is made of a midwife being present and I would suggest that this is unlikely as the vast majority, if not all, of Mary's attendants might not know she was pregnant. However, this is conjecture on my part.

Sir Nicholas Throckmorton, one of Elizabeth's most trusted ambassadors, attended Mary Stuart at Loch Leven that same July. His letter to Sir William Cecil is dated 18 July 1567, and reports that Mary refused to divorce Bothwell "but rather die, grounding herself upon this reason, taking herself to be seven weeks gone with child; by renouncing Bothwell she would acknowledge herself to be with child of a bastard, and to have forfeited her honour".

Mary had been married on 15 May 1567 to Bothwell. As Sir James Melville, Scottish Ambassador to England, wrote in his memoirs: "the Queen could not but marry him, seeing he had ravished her".

\section{Mysterious miscarriage}

Who fathered those twins and when? We should remind ourselves that there was no modern medical equipment available then, and having last year visited what is left of those rooms on Loch Leven island where Mary miscarried I can surmise that the lighting was poor. We should also ask how experienced were the midwives and doctors in identifying twins in a fetal state and at which point?

For the last 4 years I have been considering and researching the following questions:

1 Was Mary having an adulterous sexual relationship with Bothwell when separated publicly from Darnley?

2 Discovering to her horror she was pregnant, was Mary indeed fully involved in plans for Darnley's murder, or was she merely told euphemistically that Bothwell would make arrangements for all to be well?

3 By sleeping in Darnley's house the night before his death, Mary broke with her previous behaviour of keeping him at a distance. Was this an attempt to show some form of reconciliation and therefore suggest her innocence in Darnley's death?

4 Was Mary also attempting to muddy the waters by having the option of claiming, if already pregnant, that the child was her husband's?

There is the chance that Mary did have intercourse and conceive with Darnley that night and syphilis might explain the miscarriage. This latter theory, although possible, does not seem likely because she knew Darnley had received treatment for the 'Pox' and would be well aware of the contagious nature of the disease. There also seems to be no evidence that Mary herself ever showed symptoms of current or tertiary syphilis during her 44-year life. In this version of events she would then have been 5 months' pregnant with twins at Loch Leven - hardly unnoticeable, one would have thought.

It does seem an astonishing coincidence that Mary could claim that the conception occurred during her 'rape' and therefore be innocent of any earlier sexual involvement with Bothwell. Consider the small window of time in which Mary might be ovulating and then conceive during that 10-day period. Consider also that Bothwell was missing for a number of those days.

Mary's moral behaviour has been the subject of much speculation. Some have said "unsullied". I disagree. It is documented that the poet Seigneur de Chastelard was hanged after being caught hiding under her bed, with Mary only partially dressed. He claimed that she had encouraged him and that it was bad luck he had been caught. David Rizzio, Mary's musician and secretary, was murdered at Holyrood by supporters of her husband, Darnley, who believed they might have been lovers.

We should now consider Elizabeth's position. Mary (her second cousin) arrived in Carlisle having escaped from Loch Leven in 1568. Elizabeth was probably aware of all these details and probably a very great deal more.

Mary Stuart would have been viewed as a dangerous liability, a view that is supported by my research and that of others. Elizabeth probably had a very much stronger case than previously thought in holding Mary captive.

I have contacted $\mathrm{Mr}$ Tony Roberts, a consultant obstetrician and gynaecologist, and his opinion has proved invaluable and gone some considerable way towards helping shed light on this mystery. Roberts comments:

"A miscarriage could be identified as a tiny foetus perhaps as early as 8 weeks if it was well preserved and pretty easily at 10-12 weeks if it was examined closely. Remember our calculations of gestation are from the last period and not conception. So 8 weeks actually represents 6 weeks of fetal growth. Twins could certainly be identified at 12 weeks if closely examined, but it does need a sensible and weathered eye to distinguish products of conception (and other matter). If you just want to prove pregnancy, a midwife in those days should have been able to do this, but standards were low, even for a queen. Miscarriages below 12 weeks can rarely bleed to the point of endangering a woman's life so that doesn't give much away. In the end it is down to speculation and the credibility of the witnesses and, indeed, their other agendas - money, power and wanting to stay alive can all alter their veracity." 
So let us consider the options.

1 If the twins were Darnley's and were conceived in February they would be around 20-22 weeks at the time of the miscarriage and Mary's pregnancy would probably have been more widely remarked upon. This scenario also seems unlikely not only because of the estrangement but because of the reduced libido produced by the mercury syphilis treatment from which Darnley was recovering at this time. However, it would be very easy to identify twins and there could be a lot of bleeding.

2 If the twins were Bothwell's and were conceived before 24 April then twins might very plausibly have been identified by the time of the miscarriage. We are also well aware of the passion Mary had for Bothwell.

3 If the twins were Bothwell's but were conceived after 24 April they would be 12 weeks old, but only 10 weeks since conception. Identification of twins is possible but really very unlikely in poor light with so much bleeding.

I should point out that I am not alone in reflecting on this extraordinary matter. A doctor in the mid-17th century also looked with suspicion at the timings less than 100 years after Mary's death. Historians are divided on the issue, but it has been the source of much speculation about Mary's personality.

The most crucial evidence spans the centuries. The report by Nau, Mary's secretary, that Mary miscarried twins at Loch Leven Castle is pivotal, if it is accurate. Equally our current understanding of twin fetal development and miscarriage plays a crucial role as evidence. If Mary had miscarried a single fetus then this story would not have been researched much further. It is reasonable to speculate that the widowed Mary Queen of Scots had conceived by Bothwell and had used the abduction story as a cover for her condition and justification for marriage. This is not a new idea but the medical evidence given in this article brings us very much closer to the likely truth.

Did Elizabeth know all of this and more? It is documented that Elizabeth had her own ambassador attend Mary Queen of Scots at Loch Leven Castle on 18 July 1567. Did Elizabeth view Mary as an adulterer, liar and fool for men? As such, was it too dangerous to risk letting her considerable charms loose in society, so that she might threaten England repeatedly with plots and uprisings? Assuming Elizabeth had knowledge of this gives us a clearer picture of why she was so determined to hold Mary captive. It does not prove that Mary was implicated in the death of her husband Darnley, but her undoubted passion for Bothwell and the possibilities presented in this article create a damning impression. It is also interesting to note that whilst Mary was prisoner in England, no Catholic nation made a serious attempt to release her. Was there a more widely held view that Mary was better out of the way?

The real truth is that we are not entirely sure but we do know Mary was held in England, without charge, for more than 18 years, until she was implicated in a plot to overthrow Elizabeth. Mary Queen of Scots was indeed the 'daughter of debate'.

\section{Future articles}

The next article in this series will be about the birth of James VI of Scotland (James I of England).

\section{Acknowledgements}

The author would like to thank the following individuals for their help and advice: Professor R Arnott, Director of the Centre for the History of Medicine, University of Birmingham Medical School,
Birmingham; A D G Roberts, MD, FRCOG, consultant obstetrician and gynaecologist; Dr G Williams, British Museum, London; The Marie Stuart Society; Gill Taylor, midwife (and her magic wheel); Dr David Breeze, Historic Scotland, Edinburgh; and The Wellcome Library, London.

\section{Bibliography}

1 Guy, John. My Heart Is My Own: The Life of Mary Queen of Scots. London, UK: Fourth Estate/HarperCollins, 2004.

2 Mackay, James. In My End Is My Beginning: A Life of Mary Queen of Scots. Edinburgh, UK: Mainstream Publishing, 1999.

3 Eccles, Audrey. Obstetrics and Gynaecology in Tudor and Stuart England. London, UK: Croom Helm, 1982.

4 Dunne, Jane. Elizabeth \& Mary: Cousins, Rivals, Queens. London, UK: Harper Collins, 2003.

5 Nau, Claude. The History of Mary Stewart. Edinburgh, UK: Paterson, 1883.

6 Goodall, AL. The maladies of Mary Queen of Scots and her husband. The Report of Proceedings of Scottish Society of the History of Medicine, 1955-1956.

About the author

Lesley Smith is currently a postgraduate student in the Centre for the History of Medicine of the University of Birmingham, where she is developing a $\mathrm{PhD}$ in obstetrics and gynaecology in early modern Britain. She holds an honorary degree for "services to history". She makes 200-300 public appearances a year and also works as a TV historian in the UK and abroad including the USA. Lesley is also Curator of Tutbury Castle and is currently involved with a major research project with the British Museum, which is her excuse for why it is taking her so long to finish her PhD!

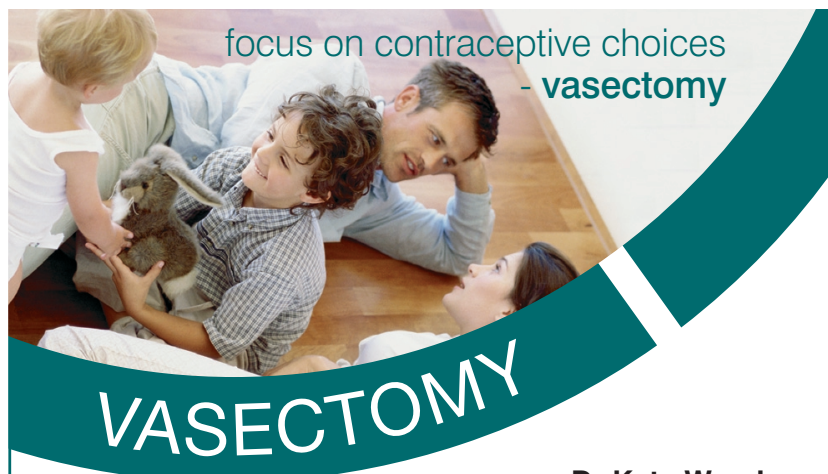

Dr Kate Worsley

Head of Medical Development - Marie Stopes International Millions of men worldwide have had a vasectomy and in the UK $13 \%$ of adult males have chosen this as their contraceptive method.

Global sexual and reproductive health agency Marie Stopes International has had over 30 years experience in providing vasectomies - performing over 130,000 since 1976

In keeping with its reputation as a world leader in medical advancement Marie Stopes International has pioneered the electrocautery non-scalpel vasectomy making the procedure easier and speedier to perform while significantly reducing early post operative complications and time taken to return to work and sexual activity.

In addition the organisation has introduced an innovative online booking system and post-treatment semen test result service enabling men who have chosen to take responsibility for their contraception to access our service speedily.

If your practice would like more information about this service please call 08451203644 for a GP information pack.

08451203644

www.mariestopes.org.uk

working with you... 